\title{
Faktor Ibu Bapa dalam Kecemerlangan Akademik Pelajar Pekak: Kajian Kes Retrospektif
}

\author{
SHAHRUL ARBA'IAH OTHMAN \\ NORZAINI AZMAN \\ MANISAH MOHD ALI \\ Universiti Kebangsaan Malaysia
}

\begin{abstract}
Abstrak: Kajian kes retrospektif ini dijalankan untuk memahami bagaimana faktor ibu bapa telah menyumbang kepada kecemerlangan akademik pelajar pekak. Kecemerlangan akademik didefinisikan sebagai kejayaan yang dicapai oleh pelajar pekak dalam peperiksaan awam hingga membolehkan mereka melanjutkan pelajaran ke peringkat diploma atau ijazah pertama di institusi pengajian tinggi. Data dikumpul dengan membuat triangulasi kepada kaedah dan sumber. Kaedah pengumpulan data yang digunakan adalah temu bual mendalam, soalan bertulis, dan analisis dokumen. Sumber-sumber kepada data merupakan ibu bapa, pelajar pekak, dan dokumen/ memorabilia. Seramai lapan orang pelajar pekak yang cemerlang dalam akademik, lapan orang ibu dan empat orang bapa pelajar tersebut dipilih menjadi peserta kajian. Temu bual mendalam telah dijalankan dengan ibu bapa terlibat. Maklumat yang dapat menyokong atau mengukuhkan kata-kata ibu bapa ini telah diperoleh secara jawapan bertulis daripada pelajar sendiri dan analisis dokumen. Hasil temu bual telah dibuat trankripsi secara verbatim dan kesimpulan yang dibuat berdasarkan analisis tema. Dapatan kajian menunjukkan kecemerlangan akademik pelajar pekak bergantung kepada dua faktor iaitu keluarga dan diri pelajar pekak sendiri. Faktor-fakor keluarga yang penting ialah sikap ibu bapa, penglibatan ibu bapa, jangkaan ibu bapa, persekitaran keluarga, dan sumber keluarga. Kajian ini memberi implikasi kepada penyediaan khidmat intervensi awal yang lebih baik, pemberian peluang pendidikan yang sama rata kepada pelajar pekak, dan penyediaan khidmat sokongan secara kolaboratif antara agensi-agensi yang terlibat.
\end{abstract}

Abstract: The purpose of this retrospective case study is to understand how family factors have contributed to the academic excellence of deaf students. Academic excellence is defined as the 
deaf student's success in the public examinations which enabled them to continue their studies at diploma or degree level. Eight deaf students who excelled in their studies, and all the mothers and four fathers of these students participated in this study. Data were gathered by triangulating several methods and sources. Methods used were in-depth interviews, written answers, and document analysis while the informants were parents, deaf students, and documents/memorabilia. In-depth interviews were carried out with the parents and supporting information was gathered in written form from the deaf students and document analysis. Data were processed using verbatim transcript analysis and were analyzed thematically. Findings showed that the deaf students' academic excellence was due to two factors, that is family and the deaf students themselves. Parental factors that are considered important are parent's attitudes, parent's involvement, parent's expectations, family environment, and family resources. This study has implications for the implementation of better early intervention services, equal opportunities in education for deaf students, and collaborations between agencies involved in providing services.

\section{PENGENALAN}

Menurut World Federation of the Deaf (2001), terdapat lebih 70 juta orang menghadapi masalah pendengaran di seluruh dunia. Masalah pendengaran atau pekak adalah kecacatan yang tidak dapat dilihat secara zahir. Hal ini berlaku kerana kebanyakan masalah kehilangan pendengaran melibatkan kerosakan kepada bahagian dalam telinga (Moores, 2001). Tinjauan literatur menunjukkan bahawa kanak-kanak pekak mempunyai kebolehan kognitif yang sama dengan kanak-kanak biasa (Moores, 2001). Bagaimanapun, didapati kebanyakan kanak-kanak pekak menunjukkan pencapaian akademik yang lebih rendah (Gargiulo, 2003; Easterbrooks \& Baker, 2002; Moores, 2001). Keadaan yang sama dapat diperhatikan di kalangan murid-murid pekak di Malaysia. Pencapaian murid-murid pekak dalam Penilaian Menengah Rendah (PMR) pada tahun 2002 menunjukkan bahawa bagi mata pelajaran Bahasa Melayu hanya enam daripada 287 calon atau 2.1 peratus yang mencapai gred B dan C (Lembaga Peperiksaan Malaysia, 2003). Tiada calon yang mencapai gred A. Mata pelajaran Sains pula, menunjukkan daripada 286 calon yang mengambil PMR hanya tujuh calon atau 2.5 peratus 
yang mencapai gred B dan C. Keputusan mata pelajaran lain seperti Bahasa Inggeris (2.5 peratus), Matematik (9.8 peratus), Geografi (3.8 peratus), Sejarah (6.7 peratus), dan Pendidikan Islam (0 peratus). Pencapaian akademik murid-murid ini adalah rendah walaupun mereka telah berada di sekolah selama dua belas hingga lima belas tahun (Peraturan-Peraturan Pendidikan (Pendidikan Khas), 1997). Sistem persekolahan di negara ini amat menitikberatkan keupayaan berbahasa sama ada dalam pengajaran dan pembelajaran harian atau pun dalam sistem pentaksiran awamnya. Tanpa kecekapan bahasa, kanak-kanak pekak sukar untuk berjaya dalam akademik berbanding dengan kanak-kanak lain (Hallahan \& Kauffman, 2000).

Namun demikian, ini tidak bermakna kanak-kanak pekak tidak boleh berjaya dalam akademik. Terdapat kajian-kajian di luar negara yang menunjukkan ada kanak-kanak pekak yang cemerlang dalam pelajaran dan beberapa bidang tertentu (Luckner \& Stewart, 2003; Holte \& Dinis, 2001; Luckner \& Muir, 2001). Beberapa orang pelajar pekak di negara ini telah berjaya melanjutkan pelajaran ke peringkat universiti dan telah memperoleh ijazah. Mereka ialah Aqlam bin Jafri, Amir Hamidi b. Abdul Manan, dan Ahmad Syukri b. Ahmad Mokhtar (Lembaga Peperiksaan Malaysia, 2001; Persatuan Ibu bapa dan Penjaga Anak Pekak Kuala Lumpur, 2000). Kejayaan Haw Ching Cher mendapat 4A dan 1B dalam Sijil Tinggi Peperiksaan Malaysia 2003 dan Yee Ke Xin memperoleh 6A dan 3B dalam Sijil Pelajaran Malaysia 2003 (PMY Newsletter, 2004) menunjukkan bahawa kanak-kanak pekak boleh berjaya jika peluang, asuhan dan didikan yang betul diberikan.

Kelahiran anak pekak ke dalam keluarga yang tidak pernah mengalami situasi seperti ini menakutkan sesetengah ibu bapa (Calderon \& Greenberg, 1999). Ibu bapa tersebut mungkin tidak pernah mengetahui apa-apa atau tidak pernah mengenali sesiapa yang pekak sebelum ini. Alper, Schloss dan Schloss (1994) mendapati kelahiran anak pekak mendatangkan kesan yang tidak dapat dielakkan ke atas keluarga. Menurut Alper et al., kanak-kanak pekak akan mempengaruhi ibu bapa dan keluarga secara peribadi, ekonomi, dan sosial setiap hari sejak lahir. Keadaan ini akan mendatangkan tekanan kepada keluarga dan mengakibatkan timbul rasa kekurangan diri, geram, dan bersalah jika tidak ditangani dengan baik (Haessly, 2001). Walau apapun kekurangan atau kelebihan yang dimiliki seseorang anak itu, ibu bapa tetap bertanggungjawab memastikan perkembangan sosial, emosi, linguistik, dan kognitif kanak-kanak dipupuk (Moores 2001; Jackson 2002). Kenyataan Haessly (2001), 
dan Alper, et al. (1994) menunjukkan betapa pentingnya peranan ibu bapa dalam memberi didikan kepada anak-anak. Ibu bapa dikatakan sebagai kumpulan rujukan pertama tentang nilai, norma dan gaya hidup yang dirujuk oleh anak-anak (Berns, 2004). Faktor ini menunjukkan bahawa ibu bapa merupakan penyumbang utama terhadap kejayaan atau kegagalan anak-anak.

Proses ini dapat difahami dengan lebih jelas apabila merujuk kepada model ekologi sosial Bronfenbrenner, teori perkembangan kognitif Vygotsky, dan teori humanistik yang diketengahkan oleh Maslow. Model ekologi sosial Bronfenbrenner menekankan bahawa ibu bapa dan persekitaran sosial memainkan peranan yang penting dalam perkembangan seseorang kanak-kanak (Kail, 2001). Teori Vygotsky pula menjelaskan bahawa interaksi sosial antara orang dewasa dengan kanak-kanak mempengaruhi perkembangan kognitif kanak-kanak (Daniels, 2001). Manakala Maslow mendapati bahawa kanak-kanak akan cuba memenuhi kehendak yang lebih tinggi jika keperluan-keperluan yang lebih rendah telah diperoleh (Crain, 2004). Secara ringkas, ketiga-tiga teori ini menunjukkan bahawa kejayaan seseorang individu amat bergantung kepada banyak pihak antaranya ibu bapa, persekitaran sosial, dan diri mereka sendiri. Kajian-kajian yang dinyatakan di atas menunjukkan bahawa faktor keluarga memainkan peranan yang penting dalam kejayaan seseorang anak.

Kecemerlangan akademik yang diraih oleh pelajar pekak bergantung kepada banyak faktor. Faktor ini mungkin disebabkan oleh tahap kecerdasan individu, tahap kehilangan pendengaran, dan umur semasa didiagnosis (Cunningham, 1999). Kajian-kajian menunjukkan faktor-faktor keluarga seperti tahap sosioekonomi (Ghate \& Hazel 2002; Steinberg \& Bain 2001), persekitaran keluarga (Brubaker, Szarkowski \& Falkenberg, 1998; Mapp \& Hudson, 1997), jangkaan ibu bapa (Huang \& Leung, 2003; Russell, 2003) dan penglibatan ibu bapa dalam pendidikan anak-anak (Miedel \& Reynolds, 2000; Yoshinaga-Itano, Synder \& Day, 1998) berperanan menentukan kejayaan atau kegagalan kanak-kanak pekak dalam bidang akademik. Kajian menunjukkan gaya keibubapaan memberi kesan terhadap pencapaian akademik kanak-kanak tanpa mengira status sosioekonomi mereka (Hill, 2001; Jackson, 2002). Kajian juga menunjukkan bahawa jika ibu bapa melibatkan diri dalam pendidikan anak-anak, pencapaian akademik anak menjadi bertambah baik (Luchuck, 1998; Simon, 2000; Kim, 2002; Shumow \& Miller, 2001). Pengkaji-pengkaji ini mendapati bahawa ibu bapa 
sebagai guru di rumah boleh menjadi penyumbang yang tidak ternilai kepada pendidikan anak-anak mereka. Peranan ibu bapa menjadi semakin penting apabila anak tersebut dikenal pasti menghadapi masalah pendengaran atau pekak (Dunst, 2002) dan penerimaan ibu bapa merupakan perkara terpenting dalam membantu kejayaan anak pekak (Luckner dan Muir, 2001). Luckner dan Muir (2001), dan Toscano, McKee dan Lepoutre (2002) mendapati ibu bapa sanggup berpindah tempat tinggal supaya anak pekak mendapat perkhidmatan yang lebih baik. Tidak dinafikan peranan yang dimainkan ibu bapa yang mempunyai anak pekak adalah penting kepada perkembangan anak tersebut (Jackson, 2002; Luckner \& Stewart, 2003). Selain itu, faktor pelajar pekak itu sendiri membantu kejayaan mereka dalam akademik. Luckner dan Muir (2001), Luckner dan Stewart (2003), dan Toscano et al. (2002) mendapati bahawa pelajar pekak berjaya kerana mereka mempunyai motivasi intrinsik yang kuat serta imej kendiri yang positif.

\section{TUJUAN KAJIAN}

Kajian ini bertujuan untuk melihat apakah faktor yang mempengaruhi kecemerlangan akademik pelajar-pelajar pekak. Persoalan khusus kajian ialah sejauh manakah faktor-faktor berikut menyumbang kepada kecemerlangan akademik pelajar pekak:

i. sumber keluarga

ii. persekitaran keluarga

iii. penglibatan ibu bapa dalam pendidikan

iv. jangkaan ibu bapa.

\section{METODOLOGI}

Kajian ini menggunakan kaedah kajian kes retrospektif. Kajian retrospektif merupakan bentuk kajian yang meninjau kembali pengalaman responden bagi mendapatkan maklumat tentang apa yang telah berlaku satu ketika dahulu bagi menjelaskan situasi kini (Miedel \& Renolds, 2000). Memandangkan responden terdiri daripada kumpulan yang berbeza, maka data telah dikutip dengan menggunakan pendekatan kualitatif pelbagai kes dan pelbagai tempat. Data telah diperoleh secara triangulasi kaedah dan sumber iaitu melalui temu bual mendalam ibu bapa, soalan bertulis kepada 
pelajar pekak dan analisis dokumen. Triangulasi digunakan untuk dua tujuan utama iaitu pengesahan data dan melengkapkan data (Arksey \& Knight, 1999). Kaedah temu bual digunakan kerana pengkaji dapat meneroka pengalaman sebenar bersifat individu dan peribadi yang telah dilalui oleh ibu bapa, dan cuba memahami makna yang diberikan terhadap pengalaman tersebut (Seidman, 1998). Temu bual juga dapat memberikan data tentang buah fikiran, apa yang diingati, sikap, perasaan dan sebagainya yang telah dilalui oleh ibu bapa. Data daripada para pelajar pekak yang cemerlang dikutip menggunakan soalan bertulis yang dikirim melalui mel elektronik. Semua temu bual telah dilakukan transkripsi secara verbatim, dibaca dan pengurangan data dilakukan. Hal yang sama dilakukan terhadap jawapan bertulis pelajar dan analisis dokumen. Dalam proses membaca dan menanda transkrip, petikan-petikan yang menarik telah dilabel dengan tajuk-tajuk tertentu. Tajuktajuk yang sama atau hampir sama dikelompokkan dan diberi kodkod tertentu dan dikategorikan. Setelah semua proses mengekod kategori selesai, kategori-kategori yang mempunyai hubungan telah diletakkan dalam kategori yang lebih luas untuk membentuk tema. Kategori, tema, subtema yang telah dibuat dan unit analisis yang dipetik daripada data telah diberikan kepada dua orang penyemak untuk dibuat semakan dan untuk mencari Nilai Pekali Persetujuan Kappa. Nilai K yang diperoleh ialah 0.99. Setelah hasil dipaparkan, makna ditentukan kepada data tersebut berdasarkan tujuan kajian dengan mengambil kira tentang kesahan dan kebolehpercayaan data yang telah dikumpul.

\section{DAPATAN KAJIAN}

Analisis data daripada temu bual lapan orang ibu, tiga orang bapa, lapan pelajar pekak dan dokumen tentang faktor-faktor yang menyumbang kepada kecemerlangan akademik pelajar pekak menunjukkan persamaan dapatan. Terdapat enam tema yang berulang iaitu; i) sikap ibu bapa, ii) persekitaran keluarga, iii) penglibatan ibu bapa dalam pendidikan, iv) jangkaan ibu bapa, v) sumber keluarga, dan vi) intervensi awal. Jawapan bertulis pelajar pekak sendiri telah menjana dua tema iaitu: i) sokongan keluarga, dan ii) khidmat sokongan. Tema-tema ini didapati memainkan peranan yang penting dalam menyumbang kepada kecemerlangan akademik pelajar pekak yang dikaji. 


\section{Sikap Ibu Bapa}

Dapatan kajian menunjukkan sikap ibu bapa yang dapat menerima kehadiran anak pekak dalam keluarga amat penting untuk perkembangan pelajar pekak dan juga keluarga tersebut. Semua ibu bapa yang ditemubual menyatakan bahawa tanpa rasa penerimaan terhadap anak, ibu bapa tidak mungkin dapat membantu anak tersebut. Kenyataan berikut yang dibuat oleh seorang ibu menggambarkan hal ini. “...mula-mula memang tak sangka tapi bila dah macam ni, saya terimalah..." Seorang bapa pula menyatakan, “...menjawab soalan tentang apakah peranan ibu bapa, anda perlu bermula dengan tahap pendidikan ibu bapa dan sikap. Kedua-dua ini adalah satu gabungan..."

Semua ibu bapa dalam kajian ini bersikap proaktif kerana mereka telah berusaha mencari maklumat yang berkaitan sebaik mereka mengetahui tentang masalah kepekakan anak. Mereka berjumpa pakar perubatan, pakar telinga, hidung, dan tekak, guruguru, badan-badan bukan kerajaan yang berkaitan, membaca bukubuku yang berkaitan, malah sepasang ibu bapa telah mengikuti kursus gaya pos. Keadaan ini menunjukkan ibu bapa tidak menunggu dan berharap bantuan datang kepada mereka tetapi berusaha mencari apa sahaja maklumat dan bantuan yang boleh diperoleh. Kajian ini juga mendapati empat orang ibu telah berhenti kerja kerana ingin menumpukan sepenuh perhatian mereka terhadap anak pekak. Malah sebuah keluarga dalam kajian ini telah berpindah dari Ipoh ke Kuala Lumpur semata-mata untuk mendapatkan perkhidmatan yang terbaik untuk anak pekak mereka. Semua ibu bapa juga telah sanggup berulang-alik ke pusat-pusat pertuturan atau sekolah untuk mendapatkan terapi. Semua pelajar pekak dalam kajian ini juga menyatakan bahawa ibu bapa mereka sangat mengambil berat tentang pelajaran mereka dan telah mula mengajar mereka menggunakan alat bantuan pendengaran, dan mengajar mereka sejak kecil.

\section{Sumber Keluarga}

Sumber keluarga dilihat dari dua aspek iaitu taraf pendidikan dan status sosioekonomi. Semua peserta kajian menyatakan bahawa taraf pendidikan dan status sosioekonomi berperanan dalam menentukan kecemerlangan akademik anak pekak. Tahap pendidikan yang dimiliki oleh ibu bapa membantu mereka mengakses maklumat dengan lebih baik dan memahami kaedah bagaimana hendak mendapatkan bantuan dan khidmat sokongan yang diperlukan. Ibu 
bapa yang berpendidikan dan berkemampuan dari segi kewangan dapat menyediakan peluang dan kemudahan yang lebih baik untuk anak-anak pekak. Ibu bapa dan pelajar pekak sendiri mengakui bahawa perbelanjaan untuk menyediakan keperluan pelajar pekak adalah tinggi. Faktor ini diakui benar oleh seorang pelajar dengan berkata, “...dari semenjak kecil hingga remaja, berpuluh-puluh ribu telah ditelan dan dibelanja untuk membeli keperluan saya iaitu makan, minum, pakaian, dan rujukan dan juga alat bantuan pendengaran. ..saya ingin membalas jasa ibu bapa yang banyak mengeluarkan duit untuk membaiki alat, beli bateri dan sebagainya berkaitan dengan pendengaran..." Status sosioekonomi keluarga yang teguh dapat menjamin segala keperluan ini diadakan. Walau bagaimanapun, ibu bapa yang mempunyai tahap pendidikan rendah juga dapat membantu anak pekak untuk berjaya disebabkan sikap mereka yang positif.

\section{Penglibatan dalam Pendidikan}

Kajian ini mendapati bahawa pelajar pekak cemerlang kerana semua ibu bapa mereka sangat mementingkan pendidikan dan mereka telah melibatkan diri dalam pendidikan anak sejak anak masih kecil. Pada masa yang sama, ibu bapa juga mempelajari apa yang diajarkan kepada anak untuk membolehkan mereka mengajar anak di rumah menggunakan teknik yang telah dipelajari. Apabila anak-anak telah mula bersedia untuk belajar, ibu bapa telah berusaha untuk mengajar dengan menggunakan pelbagai kaedah. Seorang ibu memberitahu bahawa dia telah melekatkan peralatan di rumah dengan nama peralatan tersebut supaya anak dapat melihat dan mengingati ejaannya serta tahu isyarat untuk peralatan tersebut. Empat orang ibu telah mengajar anak mereka seperti pengajaran di sekolah kerana ibu-ibu tersebut bertugas sebagai guru. Sebaliknya, enam ibu bapa lebih menekankan kepada pengajaran yang berbentuk bacaan dan penulisan dengan anak-anak pekak, dan kaedah ini menunjukkan mereka telah boleh membaca dan menulis sebelum mereka mula bersekolah. Ibu bapa didapati berusaha bersama-sama anak untuk memastikan anak-anak dapat menguasai pelajaran dengan baik. Selain mengajar di rumah, ibu bapa juga berusaha membantu anak ketika anak menghadapi kesukaran untuk mendapatkan tempat di sekolah yang menjadi pilihan dan institusi pengajian tinggi tertentu. Semua ibu bapa telah berusaha untuk bertemu dengan guru-guru, pentadbir, pegawai pelajaran, pensyarah serta pentadbir institusi pengajian tinggi bagi memastikan anak pekak mendapat hak yang sepatutnya seperti pelajar lain. Ibu bapa juga telah berjumpa guru- 
guru dan pentadbiran sekolah apabila anak mereka telah ditempatkan di sekolah berkenaan untuk menceritakan keadaan sebenar anak mereka. Usaha ini menunjukkan semua ibu bapa telah berjaya membuatkan para guru lebih memahami dan dapat membantu pelajar tersebut. Semua ibu bapa juga telah mewujudkan dan mengekalkan hubungan yang baik dengan guru-guru yang mengajar anak mereka.

\section{Jangkaan Ibu Bapa}

Semua ibu bapa yang meletakkan jangkaan yang tinggi dan berpatutan dengan kebolehan pelajar telah berjaya membolehkan anak mencapai apa yang dijangkakan. Semua ibu bapa dalam kajian ini didapati menetapkan jangkaan jangka panjang dan jangkaan jangka pendek yang realistik terhadap pelajar pekak. Jangkaan realistik bermaksud ibu bapa menetapkan jangkaan yang sepadan dengan kebolehan yang dipamerkan oleh anak mereka. Meskipun tiga orang ibu tidak meletakkan jangkaan yang tinggi tetapi selari dengan perkembangan anak tersebut, jangkaan ibu turut berubah. Di negara ini, sistem persekolahan sangat menitikberatkan pencapaian dalam peperiksaan khususnya peperiksaan awam. Apabila anak pekak dapat menunjukkan pencapaian yang baik pada satu-satu peringkat peperiksaan, jangkaan ibu tersebut didapati turut berubah. Lima pasangan ibu bapa didapati turut meletakkan jangkaan yang lebih tinggi kepada anak tersebut. Ini bermakna ibu bapa meletakkan jangkaan yang realistik terhadap kemampuan anak. Kata seorang bapa, “...kami sekarang di sini, kami ingin dia sampai ke tahap ini dan di sinilah kami akan berusaha untuk mengurangkan jurang yang ada..." Jangkaan ibu bapa juga didapati selari dengan bantuan yang dihulurkan kepada anak pekak. Ibu bapa berusaha bersungguhsungguh untuk menyediakan pendidikan terbaik kepada anak pekak. Pelajar pekak didapati berjaya disebabkan jangkaan ibu bapa terhadap mereka. Keyakinan ibu bapa ini telah memotivasikan pelajar pekak untuk berusaha lebih gigih sehingga membolehkan mereka mencapai kejayaan cemerlang dalam akademik.

\section{Persekitaran Keluarga}

Kajian ini melihat persekitaran keluarga dari segi gaya keibubapaan, pertautan keluarga, dan tekanan ibu bapa. Kajian ini menunjukkan semua ibu bapa telah mengamalkan gaya keibubapaan yang sederhana atau bersifat autoritatif. Pengawasan dan pemantauan yang dilakukan ke atas anak-anak juga tidak dibezakan. Kajian ini juga mendapati semua anak pekak turut dilibatkan dalam perbualan harian dan semua aktiviti keluarga. Semua ibu bapa juga 
menggalakkan semua anak-anak lain melibatkan diri dalam aktiviti yang disertai oleh anak pekak. Sifat kekeluargaan yang mesra dan menerima telah membuatkan anak pekak mampu bersaing dengan ahli keluarga lain sehingga membolehkan mereka cemerlang dalam akademik.

Terdapat tiga orang ibu dan dua orang bapa dalam kajian ini yang menghadapi tekanan berkaitan kelahiran anak pekak tersebut seperti kata mereka, “...kawan-kawan bukan nak menyokong tapi menghina banyak, lagi-lagi kalau orang kampung. Kadang-kadang kalau nak balik kampung, saya kena fikir balik. Saya terpaksa redha walau cacian amatbanyak..." Namun demikian perasan tertekan, rasa malu dan pandangan negatif masyarakat setempat telah mendorong keluarga yang berkenaan untuk lebih berusaha memajukan anak pekak ini. Kata mereka “...bila dah bela anak macam ni, sejak dari cakap-cakap orang, menaikkan semangat kita. Lagi orang kata, lagi timbul semangat..." Pegangan agama yang teguh di kalangan ibu bapa juga membolehkan mereka menyerap segala tekanan yang dihadapi. Secara keseluruhan kajian ini menunjukkan ibu bapa telah dapat menyediakan persekitaran keluarga yang kondusif untuk pembesaran anak-anak pekak dan ini telah membolehkan anak-anak mencapai kecemerlangan dalam akademik.

\section{Intervensi Awal}

Kajian ini melihat intervensi awal sebagai satu usaha terancang untuk meningkatkan perkembangan bayi dan kanak-kanak yang berisiko untuk lambat berkembang disebabkan masalah pendengaran yang dialami. Dapatan kajian menunjukkan anak-anak yang dikenal pasti pada peringkat awal mempunyai kepekakan adalah lebih berjaya dalam akademik berbanding dengan mereka yang lewat dikenal pasti. Hal ini kerana anak-anak tersebut dapat diberi intervensi sebaik masalah dikenal pasti. Intervensi awal ini antara lain ialah memakaikan alat bantuan pendengaran (enam orang), menyediakan latihan komunikasi (lapan orang), dan mengajar anak membaca dan menulis (enam orang).

\section{PERBINCANGAN}

Berdasarkan analisis, kajian ini menunjukkan faktor ibu bapa iaitu sikap, sumber keluarga, penglibatan dalam pendidikan, jangkaan, persekitaran keluarga, dan intervensi awal berperanan dalam 
menentukan kecemerlangan pelajar pekak. Ibu bapa yang dapat menerima kehadiran anak pekak dalam keluarga dan sentiasa bersikap positif terhadap anak tersebut mempunyai peluang yang lebih baik untuk menjadikan pelajar pekak cemerlang dalam akademik. Hasil kajian ini menyokong dapatan kajian Luckner dan Muir (2001) yang menunjukkan betapa pentingnya penerimaan ibu bapa terhadap anak pekak. Luckner dan Muir (2001) menekankan tentang penerimaan. Jika kanak-kanak pekak tidak diterima, mereka akan menghadapi masalah sepanjang hidup mereka. Kajian yang dijalankan ini mendapati ibu bapa sanggup berpindah tempat tinggal semata-mata untuk mendapatkan perkhidmatan yang lebih baik untuk anak pekak. Keputusan ini selari dengan kajian Luckner dan Muir (2001), dan Toscano et al. (2002) yang menunjukkan ibu bapa telah melakukan perkara yang sama iaitu berpindah tempat tinggal supaya anak pekak mendapat perkhidmatan yang lebih baik, dan ibu bapa berkorban masa, tenaga, dan wang ringgit untuk menghantar anak untuk mendapatkan terapi pertuturan.

Dapatan kajian juga menunjukkan pertautan keluarga yang erat, pegangan agama yang kukuh, gaya keibubapaan yang betul dan ibu bapa yang berupaya menyerap tekanan telah dapat mendidik anak pekak untuk berjaya. Faktor ini selari dengan kajian Jackson (2002) yang mendapati gaya keibubapaan memberi kesan terhadap pencapaian akademik dan cara kerja kanak-kanak. Dapatan ini juga menyamai dapatan kajian Hill (2001), sifat ibu bapa yang mesra dan menerima, berkait rapat dengan pencapaian prabacaan dan pramatematik kanak-kanak. Anak-anak yang mempunyai ibu bapa yang garang menunjukkan pencapaian yang rendah. Dapatan ini juga selari dengan dapatan kajian Brubaker et al. (1998) yang menyatakan bahawa disiplin yang tidak tekal dan deraan yang dilakukan oleh ibu bapa meningkatkan kekerapan masalah tingkah laku di kalangan anak-anak. Mapp dan Hudson (1997) pula mendapati ibu bapa yang mempunyai pegangan agama yang kukuh, dapat menghadapi tekanan dengan lebih baik. Luckner dan Muir (2001) menyatakan bahawa persekitaran keluarga adalah konteks yang penting untuk pembangunan sosial, emosi, kognitif dan fizikal seseorang anak.

Kajian ini mendapati bahawa semakin tinggi tahap penglibatan ibu bapa dengan anak pekak, anak-anak mereka lebih berjaya dalam akademik. Ibu bapa yang telah mula mengajar anak sejak kecil, mempelajari komunikasi yang digunakan anak pekak, mengambil bahagian dalam pendidikan anak sama ada di sekolah atau dalam komuniti dapat membantu anak untuk cemerlang. Kajian 
lepas juga mendapati bahawa penglibatan ibu bapa mempunyai kesan positif terhadap kemajuan anak. Miedel dan Reynolds (2000) dan Sandra (2000) menegaskan apabila ibu bapa terlibat dalam pendidikan anak-anak, anak-anak akan menunjukkan peningkatan pencapaian dalam ujian, hadir ke sekolah dengan lebih kerap dan menyiapkan kerja sekolah dengan lebih baik. Anak-anak juga akan mempamerkan tingkah laku dan sikap yang lebih positif, dan akan melanjutkan pelajaran ke tahap lebih tinggi. Sementara kajian-kajian oleh Ngeow (1999), Schargel dan Smink (2001), Senechal, Leferre, Hudson dan Lawson (1998) dan Epstein, Simon dan Salinas (1997) berkaitan penglibatan ibu bapa mendapati bahawa orang yang paling tepat percaya tentang kejayaan anak di sekolah ialah apabila ibu bapa anak-anak tersebut dapat menyediakan persekitaran yang menggalakkan pembelajaran, dan melibatkan diri dalam pendidikan anak sama ada di rumah, di sekolah atau dalam komuniti.

Pelajar pekak didapati berjaya disebabkan jangkaan ibu bapa terhadap mereka. Jangkaan tinggi tetapi realistik yang diletakkan oleh ibu bapa membantu pelajar-pelajar untuk berjaya. Keyakinan yang tinggi ini telah memotivasikan pelajar pekak untuk berusaha lebih gigih dan akhirnya membolehkan mereka mencapai kejayaan cemerlang dalam akademik. Dapatan kajian ini selari dengan dapatan kajian Huang dan Leung (2003), Toscano et al. (2002), Schargel dan Smink (2001), dan Huang dan O'Neil (1997). Huang dan Leung (2003) melihat bahawa jangkaan ibu bapa memainkan peranan penting dalam pencapaian matematik anak-anak. Mereka mendapati bahawa anak-anak yang mempunyai ibu bapa yang menetapkan jangkaan yang tinggi telah mendapat pencapaian matematik yang lebih tinggi. Huang dan O’Neil (1997) juga mendapati murid-murid berprestasi tinggi dan rendah menyatakan jangkaan keluarga dan daya usaha adalah komponen penting yang menentukan kejayaan mereka. Murid-murid yang merasakan ibu bapa mereka mempunyai jangkaan yang tinggi juga mempamerkan daya usaha yang tinggi dan mempercayai kebolehan diri sendiri. Toscano et al. (2002) dan Schargel dan Smink (2001) juga mendapati jangkaan tinggi dan munasabah yang ditetapkan keluarga termasuk jangkaan oleh datuk dan nenek telah membuatkan pelajar pekak berjaya dalam pelajaran.

Sumber keluarga penting bagi memastikan anak pekak mendapat segala perkhidmatan sokongan yang diperlukan. Kajian ini menyokong dapatan kajian Hanson (1996) tetapi menolak dapatan kajian Kohl (2000). Bagi Hanson sumber keluarga penting untuk membolehkan anak-anak berjaya dalam pelajaran terutama 
dalam bidang yang memerlukan pembiayaan yang tinggi. Sementara Kohl mendapati bahawa ibu bapa yang berpendidikan tinggi lebih melibatkan diri dalam pendidikan anak-anak. Dalam kajian ini, ibu bapa yang kurang berpendidikan juga dikesan sangat mengambil berat dan melibatkan diri dengan anak-anak pekak. Apa yang lebih penting ialah sikap dan kesediaan ibu bapa untuk membantu anak pekak berjaya.

Anak-anak yang dikenal pasti mempunyai kepekakan pada peringkat awal, didapati lebih berjaya dalam akademik berbanding mereka yang lewat dikenal pasti kebanyakannya. Faktor ini kerana anak-anak tersebut dapat diberi intervensi awal sebaik masalah ini dikenal pasti. Intervensi awal yang diberikan oleh ibu bapa dalam kajian ini termasuk memakaikan alat bantu dengar, latihan komunikasi, dan sosialisasi diri. Toscano et al. (2002) menegaskan bahawa pencapaian kanak-kanak bergantung kepada intervensi awal yang diterima. Prendergast et al. (2002) pula menyatakan bahawa kegagalan untuk mengadakan komunikasi berkesan pada umur muda mempunyai kesan negatif terhadap semua aspek perkembangan psikologi dan kesihatan mental kanak-kanak pekak.

\section{IMPLIKASI DAN CADANGAN}

Berdasarkan kepada dapatan kajian ini, beberapa perkara perlu diberi perhatian bagi memastikan pelajar pekak mendapat bantuan dan sokongan yang diperlukan untuk cemerlang dalam akademik.

\section{Intervensi Awal}

Dapatan kajian menunjukkan bahawa intervensi awal merupakan faktor yang juga penting dan dapat menjana potensi pelajar pekak. Yoshinaga-Itano et al. (1998) melaporkan bahawa kanak-kanak yang menerima khidmat intervensi awal dan masalah kepekakan mereka telah dikenal pasti sebelum berumur enam bulan menunjukkan secara signifikan skor bahasa yang lebih baik. Pengesanan awal kepekakan membolehkan intervensi awal disediakan. Khidmat pengesanan awal terhadap bayi yang baru lahir menggunakan Automated Auditory Brainstem Response (AABR) dan Otaocoustics Emissions (OAE) telah mula dilaksanakan di beberapa hospital di negara ini tetapi khidmat tersebut tidak dijalankan secara meluas. Oleh itu, khidmat tersebut perlu dilaksanakan secara meluas dengan menjalankan pengesanan awal ke atas setiap bayi yang baru lahir khususnya 
bayi yang berisiko tinggi. Intervensi awal pula hendaklah diberikan sebaik sahaja bayi dikenal pasti menghadapi risiko kepekakan. Menurut Brown (2005) intervensi awal amat penting kepada kanakkanak pekak kerana kehilangan pendengaran memberi kesan kepada pemerolehan bahasa pertuturan. Bahasa juga digunakan untuk pengajaran, pembelajaran dan interaksi sosial. Intervensi awal dan khidmat nasihat kepada ibu bapa terlibat mungkin dapat membantu ibu bapa menghadapi keadaan sukar tersebut dengan lebih baik dan memberi mereka panduan tentang kaedah yang betul membantu anak pekak. Di samping itu, program-program outreach yang baru dimulakan oleh Jawatankuasa Inter-agensi Program Pembangunan Kanak-Kanak di Malaysia perlu diperluaskan agar satu sistem sokongan yang lengkap dan menyeluruh dapat dinikmati oleh semua ibu bapa yang memerlukannya.

\section{Menyediakan Peluang Pendidikan yang Sama Rata}

Pelajar pekak yang cemerlang dalam pelajaran semakin hari semakin bertambah. Oleh itu ruang dan peluang yang sama rata hendaklah diberikan kepada golongan ini. Dapatan kajian berdasarkan pengalaman yang diceritakan oleh ibu bapa menunjukkan bahawa pelajar pekak tidak mendapat hak yang sama rata seperti pelajar lain meskipun pencapaian mereka dalam pelajaran sangat cemerlang. Pelajar pekak dalam kajian ini menghadapi diskriminasi untuk mendapatkan tempat di sekolah-sekolah dan institusi pengajian tinggi awam tertentu. Akta Pendidikan 1996 (Peraturan-peraturan Pendidikan [Pendidikan Khas]) 1997 yang berkuatkuasa pada 1 Januari 1998, telah menetapkan bahawa setiap murid dengan keperluan khas yang boleh dididik adalah layak untuk menghadiri program pendidikan khas. Salah satu program pendidikan khas yang terkandung dalam akta ini ialah program pendidikan inklusif bagi murid-murid berkeperluan khas yang boleh ditempatkan di dalam kelas biasa bersama-sama murid-murid biasa. Pihak pentadbiran sekolah dan institusi pengajian tinggi hendaklah memeriksa semula amalan-amalan yang diguna pakai di institusi masing-masing agar ia tidak bercanggah dengan Akta Pendidikan 1996 (Peraturan-peraturan Pendidikan [Pendidikan Khas]) 1997. Seharusnya golongan pelajar kurang upaya yang cemerlang diberi biasiswa kerana mereka sangat memerlukan dan kejayaan mereka sepatutnya diberi pengiktirafan yang sewajarnya agar menjadi ikutan pelajar kurang upaya yang lain. 


\section{Kolaborasi antara Agensi}

Pada masa ini terdapat beberapa perkhidmatan yang disediakan oleh agensi kerajaan dan badan bukan kerajaan untuk membantu kanakkanak pekak. Menurut risalah yang diterbitkan oleh Jawatankuasa Inter-agensi Program Perkembangan dan Pembangunan KanakKanak Negara (2003), Kementerian Kesihatan misalnya menyediakan pemulihan pertuturan dan pemulihan pendengaran. Jabatan Kebajikan Masyarakat mendaftar dan mengeluarkan kad kenal diri orang kurang upaya (OKU), mengadakan Pemulihan Dalam Komuniti (PDK), dan menyediakan perkhidmatan luar seperti bantuan, geran pelancaran dan elaun pekerja cacat. Kementerian Pelajaran pula menyediakan program pendidikan prasekolah hingga sekolah menengah. Badan bukan kerajaan pula menyediakan pusat harian dan pusat latihan, program intervensi awal, bahasa isyarat, kumpulan sokongan ibu bapa, pemulihan dalam komuniti, kaunseling dan sebagainya. Situasi ini bererti dasar untuk mewujudkan jawatankuasa inter-agensi telah dilaksanakan. Walau bagaimanapun, dapatan menunjukkan agensi-agensi ini menjalankan aktiviti secara terpisah-pisah. Hal ini berlaku mungkin disebabkan tidak ditetapkan mana-mana pegawai atau agensi untuk mengetuai dan memantau aktiviti yang dilaksanakan oleh pelbagai agensi dalam jawatankuasa tersebut. Maka, cadangan agar Kementerian Pelajaran khususnya Bahagian Pendidikan Khas (BPK) dilantik sebagai agensi yang mengetuai jawatankuasa inter-agensi ini kerana kanak-kanak ini akan berada di sekolah dari usia empat tahun sehingga mereka tamat tingkatan lima. Sebahagian besar masa kanak-kanak ini adalah di bawah kendalian Kementerian Pelajaran, oleh itu wajarlah Kementerian Pelajaran dipertanggungjawabkan untuk mengetuai jawatankuasa ini. Kolaborasi antara agensi-agensi ini sepatutnya ditingkatkan lagi dengan penyaluran terus maklumat tentang jumlah kelahiran baru kanak-kanak berkeperluan khas khususnya kanak-kanak pekak, buta dan lain-lain kecacatan kepada BPK bagi membolehkan BPK menyediakan unjuran keperluan pendidikan dari segi latihan guru, penyediaan kelas/sekolah, keperluan pengajaran dan pembelajaran, dan sebagainya. Segala maklumat tentang pendidikan pelajar berkeperluan khas yang menuntut di institusi pengajian tinggi juga hendaklah disalurkan kepada BPK supaya BPK dapat menjadi perantara kepada ibu bapa dan pelajar yang memerlukan bantuan. 


\section{KESIMPULAN}

Faktor untuk mencapai kejayaan yang cemerlang dalam akademik bukanlah satu perkara yang mudah, lebih-lebih lagi bagi pelajar pekak. Banyak halangan dan rintangan yang terpaksa mereka dan keluarga mereka tempuhi untuk mencapai kecemerlangan tersebut. Dapatan kajian ini menunjukkan bahawa semua peserta kajian mempunyai pandangan yang sama tentang beberapa perkara. Mereka berpandangan bahawa faktor ibu bapa yang terdiri daripada sikap ibu bapa, sumber keluarga, persekitaran keluarga, penglibatan ibu bapa dalam pendidikan, dan jangkaan ibu bapa, merupakan antara petunjuk kepada kecemerlangan pelajar pekak dalam akademik. Sehubungan itu, ibu bapa mempunyai tanggung jawab dan peranan yang sangat besar bagi menentukan hala tuju anak pekak di masa hadapan.

\section{RUJUKAN}

Akta Pendidikan 1996 (Peraturan Pendidikan Khas 1997). Surat Ikhtisas Bil. 5/1998. KP (BS) 8591/ Jld XIV (5). Pejabat Ketua Pengarah Pendidikan Malaysia.

Alper, S. K., Schloss, P. J., \& Schloss, C. N. (1994). Families of students with disabilities: Consultation and advocacy. Needham Heights: Allyn \& Bacon.

Arksey, H., \& Knight, P. (1999). Interviewing for social scientists. London: Sage Publications.

Berns, R. M. (2004). Child, family, school, community (6th ed.). Australia: Thomson.

Ballantine, J. H. (2001). The sociology of education: A systematic analysis (5th ed.). New Jersey : Prentice-Hall Inc.

Bogdan, R. C., \& Biklen S. K. (2003). Qualitative research for education: An introduction to theories and methods (4th ed.). Boston: Allyn \& Bacon.

Brown, P. M. (2005, June). Early intervention-the critical first years. Paper presented at Workshop on Early Intervention for Children with Hearing Impairment. Sunway Lagoon Resort Hotel Bandar Sunway, Selangor, Malaysia.

Brown, P. M., \& Carey-Sargeant, C. (2001). Assessing early spoken language interaction between a hearing mother and an infant with profound hearing loss. Deafness and Education International, 3 (2), 49-61. 
Brubaker, R., Szarkowski, A., \& Falkenberg, S. (1998). A preliminary study of parenting behavior and conduct problems in children who are deaf and hard-of-hearing. Retrieved June 18, 2003, from http://www.psychology. eku.edu/ BRUBAKER/ HPDKFDBK.htm.

Calderon, R., \& Greenberg, M.T. (1999). Stress and coping in hearing mothers of children with hearing loss: Factors affecting mothers and child adjustment. American Annals of the Deaf, 144, 7-23.

Creswell, J. W. (1994). Research design: Qualitative \& Quantitative Approaches. Thousand Oaks: Sage Publications.

Crain, W. C. (2004). Theories of development: Concept and applications (5th ed.). New Jersey: Prentice Hall.

Cunningham, L. (1999). The identification of early factors related to academic achievement among deaf students. Retrieved June 18, 2003, from http://www sign-lang.uni-hamburg.de/ BibWeb/Lidat.acgi?ID=50240.

Daniels, H. (2001). Vygotsky and pedagogy. London: RoutledgeFalmer.

Dunst, C. (2002). Family-centred practices: Birth through high school. The Journal of Special Education, 36 (3), 139-147.

Easterbrooks S. R., \& Baker, S. I. (2002). Language learning in children who are deaf and hard of hearing : Multiple pathways. Boston: Allyn \& Bacon.

Epstein, J. C. (1995). School/family/community partnerships: Caring for the children we share. Phi Delta Kappan, 701-712.

Epstein, J. L. Simon, B. S., \& Salinas, K. C. (1997, Sept.). Involving parents in homework in the middle grades. Phi Delta Kappa Research Bulletin, 18.

Gargiulo, R. M. (2003). Special eduation in contemporary society: An introduction to exceptionality. Belmont: Wadsworth/ Thomson Learning.

Ghate D., \& Hazel, N. (2002). Parenting in poor environment: Stress, support and coping. London: Jessica Kingsley Publishers.

Haessly, J. (2001). Mothering sons with special need. ln. O'Reily, A. (Ed.), Mothers and sons: Feminism, masculinity, and the struggle to raise our sons. New York: Routledge.

Hallahan, D. P. \& Kauffman, J. M. (2000). Exceptional learners: Introduction to special education (8th ed.). Needham Heights: Allyn \& Bacon. 
Hanson, S. L. (1996). Gender, family resources and success in science. Journal of Family Issues, 17 (1), 83-113

Hill, N. E. (2001). Parenting and academic socialization as they relate to school readiness: The roles of ethnicity and family income. Journal of Educational Psychology, 93 (4), 686-697.

Holte, M. C., \& Dinis, M. C. (2001). Self-esteem enhancement in deaf and hearing women: Success stories. American Annals of the Deaf, 146 (4), 348-354.

Huang, D., \& O'Neil, H. F. (1997). The role of parental effort and self-efficacy in the achievement of high and low track high school students in Taiwan. Retrieved June 3, 2003, from http: //www.ericae.net/ericdb/ED41524.htm.

Huang, R., \& Leung, F. K. S. Parental influence on Chinese children's mathematics learning. Retrieved June 3, 2003, from http://www.ath.admu.edu.ph/tsg22/huang. html.

Jawatankuasa Inter-agensi Program Perkembangan dan Pembangunan Kanak-Kanak Negara. (2003). Perkhidmatan kanak-kanak kurang upaya. Risalah.

Jackson, E. B. (2002). The impact of parenting styles on adolescent academic achievement and classroom behavior. (Doctoral dissertation, Universiti Capella, 2002). Retrieved May 21, 2003, from http//wwwlib.umi.co./dissertations/ preview_ all/3064154.

Kail, R.V. (2001). Children and their development (2nd ed.). New Jersey: Prantice-Hall.

Kim, E. (2002). The relationship between parental involvement and children's educational achievement in the Korean immigrant family. Journal of Comparative Family Studies, 33 (4), 529540.

Kohi, G. O. Lengua, L. J., \& Mc Mahon, R. J. (2000). Parent involvement in school: Conceptualizing multiple dimensions and their relation with family and demographic risk factors. Journal of School Psychology, 38, 501-523.

Lembaga Peperiksaan Malaysia (2001). Keputusan Peperiksaan Awam.

Lembaga Peperiksaan Malaysia (2003). Laporan Moderasi.

Luchuck, V. L. (1998). The effects of parent involvement on student achievement. Unpublished master's thesis, Salem-Teikyo University. 
Luckner, J. L., \& Muir, S. (2001). Successful students who are deaf in general education settings. American Annals of the Deaf, 146 (5), 435-446.

Luckner, J.L., \& Stewart, J. (2003). Self-assessments and other perceptions of successful adults who are deaf: An initial investigation. American Annals of the Deaf, 148 (3), 243250.

Mapp, I., \& Hudson, R. (1997). Stress and coping among African American and Hispanic parents of the deaf. American Annals of the Deaf, 144, 48-56.

Miedel, W.T., \& Reynolds, A. J. (2000). Parent involvement in early intervention for disadvantage children: Does it matter? Journal of School Psychology, 37 (4), 379-402.

Moores, D. F. (2001). Educating the deaf: Psychology, principles, and practises (5th ed.). Boston: Houghton Mifflin.

Ngeow, K. Y. H. (1999). Online resources for parent/family involvement. [ED 432775]. Retrieved April 4, 2005.

Persatuan Ibu bapa dan Penjaga Anak Pekak Kuala Lumpur. (2000). Buletin PESIBA. Kuala Lumpur: Persatuan Ibubapa dan Penjaga Anak Pekak Kuala Lumpur.

PMY Newsletter. (2004, April-June).

Prendergast, S. G., Lartz, M. N., \& Fiedler, B. C. (2002). Ages of diagnosis, amplification, and early intervention of infants and young children with hearing loss: Findings from parent interviews. American Annals of the Deaf, 147 (1), 24-29.

Robson, C. (2002). Real world research (2nd ed.). Oxford: Blackwell Publishers.

Russell, F. (2003). The expectations of parents of disabled children. British Journal of Special Education, 30 (3).

Sandra, K. (2000). Parenting and career development. ED440251. (ERIC Digest No. 214).

Schargel, F. P., \& Smink, J. (2001). Strategies to help solve our school dropout problem. Eye on education. Larchmont: New York.

Seidman, I. (1998). Interviewing as qualitative research: a guide for researchers in education and social sciences (2nd ed.). New York: Teachers College Press.

Senechal, M., LeFevre, J., Hudson, F. \& Lawson, F. P. (1998). Differential effects of home literacy experiences on the development of oral and written language. Reading Research Quarterly, 32, 96-116. 
Shumow, L., \& Miller, J. D. (2001). Parents' at-home and at-school academic involvement with young adolescents. Journal of Early Adolescence, 21 (1), 68-91.

Simon, B. S. (2000). Predictors of high school and family partnerships and the influence of partnership on student success. (Doctoral dissertation Johns Hopkins University).

Steinberg, A., \& Bain, L. J. (2001). Hearing loss. In. Batshaw, M.L. When your child has a disability. Maryland: Paul H. Brooks Publishing.

Toscano, R. M., McKee, B. \& Lepoutre, D. (2002). Success with academic English: Reflections of deaf college students. American Annals of the Deaf, 147(1), 5-23.

WFD News: Magazine of the World Federation of the Deaf. (2001). 14 (2), 25.

Yin, R. K. (1994). Case study reseach:Design and methods (3rd ed). Thousand Oaks: Sage Publications.

Yoshinaga-Itano, C., Synder, L. S., \& Day, D. (1998). The relationship of language and symbolic play in children with hearing loss. The Volta Review, 100 (3), 135-164. 